\title{
Article \\ Climate Benefit of Different Tree Species on Former Agricultural Land in Northern Europe
}

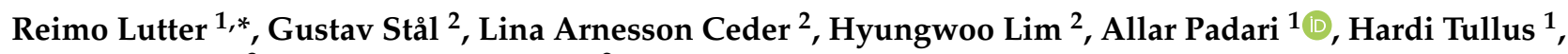 \\ Annika Nordin ${ }^{3}$ and Tomas Lundmark ${ }^{2}$ \\ 1 Institute of Forestry and Rural Engineering, Estonian University of Life Sciences, Kreutzwaldi 5, \\ EE-510 06 Tartu, Estonia; allar.padari@emu.ee (A.P.); hardi.tullus@emu.ee (H.T.) \\ 2 Department of Forest Ecology and Management, Swedish University of Agricultural Sciences, \\ Skogsmarksgränd 17, SE-901 83 Umeå, Sweden; gustav.stal@slu.se (G.S.); lina.arnesson.ceder@slu.se (L.A.C.) \\ hyungwoo.lim@slu.se (H.L.); tomas.lundmark@slu.se (T.L.) \\ 3 Department of Forest Genetics and Plant Physiology, Swedish University of Agricultural Sciences, \\ Skogsmarksgränd 17, SE-901 83 Umeå, Sweden; annika.nordin@slu.se \\ * Correspondence: reimo.lutter@emu.ee
}

check for

updates

Citation: Lutter, R.; Stål, G.;

Arnesson Ceder, L.; Lim, H.; Padari,

A.; Tullus, H.; Nordin, A.; Lundmark,

T. Climate Benefit of Different Tree

Species on Former Agricultural Land in Northern Europe. Forests 2021, 12,

1810. https://doi.org/10.3390/

f12121810

Academic Editors: Jānis Brizga and Joana Amaral Paulo

Received: 25 November 2021

Accepted: 15 December 2021

Published: 20 December 2021

Publisher's Note: MDPI stays neutral with regard to jurisdictional claims in published maps and institutional affiliations.

Copyright: (c) 2021 by the authors. Licensee MDPI, Basel, Switzerland. This article is an open access article distributed under the terms and conditions of the Creative Commons Attribution (CC BY) license (https:// creativecommons.org/licenses/by/ $4.0 /)$.

\begin{abstract}
The new European Union Forest Strategy for 2030 aims to plant an additional 3 billion trees on non-forest land to mitigate climate change. However, the choice of tree species for afforestation to achieve the maximum climate benefit is unclear. We compared the climate benefit of six different species in terms of carbon (C) sequestration in biomass and the harvested wood substitution in products to avoid carbon dioxide $\left(\mathrm{CO}_{2}\right)$ emissions from fossil-based materials over the 100-year period by afforesting about $\frac{1}{4}$ of the available area in northern Europe. The highest climate benefit was observed for larch, both at a stand scale (1626 Mg CO 2 eqv. ha $\left.{ }^{-1}\right)$ and at the landscape level for the studied scenario (579 million $\mathrm{Mg} \mathrm{CO}_{2}$ eqv.). Larch was followed by Norway spruce, poplar, hybrid aspen and birch, showing a climate benefit about $40-50 \%$ lower than that for larch. The climate benefit of willow was about 70\% lower than larch. Willow showed 6-14-fold lower C stocks at the landscape level after 100 years than other tree species. The major climate benefit over the 100-year period comes from wood substitution and avoided emissions, but $C$ stock buildup at the landscape level also removes significant amounts of $\mathrm{CO}_{2}$ already present in the atmosphere. The choice of tree species is important to maximize climate change mitigation.
\end{abstract}

Keywords: forest carbon; climate change; carbon substitution; willow; poplar; hybrid aspen; Norway spruce; silver birch; larch

\section{Introduction}

In principle, forest contributes to climate change mitigation in two ways. Through its growth, forest can absorb carbon dioxide $\left(\mathrm{CO}_{2}\right)$ that has already entered the atmosphere and store it in biomass. In this way, the forest can buffer $\mathrm{CO}_{2}$ emissions from other societal sectors. Forest growth can also be harvested and transformed into renewable products that can replace fossil-based products and cement [1-3]. In this way, fossil dependence and the addition of new $\mathrm{CO}_{2}$ that did not previously exist in the atmospheric cycle are reduced. A challenge for climate work is thus to maintain, and preferably increase, the carbon $(C)$ sink at the same time as needing to harvest more raw material to replace oil and cement [4-6]. To meet the climate challenge, existing forests need to be managed even more actively and new forests need to be established to ensure sustainable and resource-efficient development for the next decades [6-9]. At the same time, food security and environmental conservation must not be negatively impacted $[10,11]$.

The forest industry is one of the Nordic and Baltic countries' most important business sectors. Managed forests provide raw materials for products and services, including boards, planks, pulp, paper, cardboard, packaging, biofuel, etc. $[12,13]$. The modern biotechnology 
industries of wood chemicals and fiber-polymer composites as substitutes for fossil-based materials are expected to increase the demand for wood even more in the region [14]. Such increasing demand for woody biomass by the modern bio-based economy, next to the expected increase also in the traditional wood industries in the Nordic and Baltic region, will increase the demand of raw material from forests and therefore raise a potential conflict with nature conservation and biodiversity $[15,16]$, as well as jeopardizing the current $C$ sink that needs to be secured and preferably increased in accordance with the Paris Agreement [17].

One solution to avoid these conflicts and to avoid a wood deficit is to expand the area of forestland from the reserve of non-forested land [18-20]. This has been recognized by the European Union (EU) commission, and one of the main actions of the new EU Forest Strategy for 2030 is to plant an additional 3 billion trees on non-forested land and to mitigate climate change and enrich biodiversity [20]. Recent overviews show that up to 1.8-2.6 million ha of available agricultural land can be afforested in northern Europe (Denmark, Estonia, Finland, Latvia, Lithuania and Sweden) [13], and in total, about 4.8 million ha in Europe [20], which shows that there are good conditions for achieving the set goals.

Short-rotation forestry has proven to be a working alternative on abandoned agricultural land and there are good conditions for increasing both the $\mathrm{C}$ density in the landscape and the supply of forest raw materials in the future $[13,18,21]$. Usually, the rotation cycle can vary from 5 to 50 years depending on site conditions and tree species [18]. Moreover, woody tree species have several advantages over agricultural cropping systems, including lower nutrient runoff, less soil disturbance, lower greenhouse gas emissions and in many cases, local and regional biodiversity enrichment [22-25].

One of the major challenges for afforesting former agricultural land is to select the most appropriate tree species to achieve maximum climate benefit via $C$ sequestration and substitution of cement and fossil-based materials. To counteract climate change, one needs to consider both how much $\mathrm{CO}_{2}$ can be removed from the atmosphere by changing cropping systems, and also what long-term flow of raw material can be obtained to replace the use of oil and cement.

There are several empirical studies about suitable tree species for afforesting agricultural land in various parts of northern Europe, such as willow [26,27], alder [28,29], birch [30,31], hybrid aspen [32,33], poplar [34-36], spruce [37,38] and larch [39]. These studies report very high production of biomass and shorter rotation cycles compared to the same species growing on forestland. For example, a mean annual increment (MAI) up to $5-10 \mathrm{Mg}$ of dry material ha ${ }^{-1}$ year $^{-1}$ is common for the tree species mentioned. However, the species are rarely compared side-by-side on sites with homogenous growth conditions [40].

When calculating the climate benefit of afforestation, it is not enough to just focus on MAI, one must also consider how the average $C$ stock changes over time when changing cropping systems and which forest products the new cropping system can supply with raw materials to substitute energy-intensive materials and fossil-based products $[2,4,6]$. The removal of $\mathrm{CO}_{2}$ from the atmosphere related to changing land-use to forestry is a one-time event, as the average $C$ stock over a rotation cycle is normally higher than for abandoned agricultural land, but also because it builds up and supports a larger $C$ stock in forest products when the harvest increases. This is a one-off effect as a new equilibrium is reached after the first rotation cycle, and for the following cycles, there is no further change in the average $C$ stocks. Substitution effects, on the other hand, are additive and contribute to additional climate benefits as long as the forest continues to be managed and harvested. The amount of avoided $\mathrm{CO}_{2}$ emissions depends on the use and recycling of wood material, i.e., tree species [3].

Shorter rotation cycles ( $<10$ years, e.g., willow) provide an immediate and high supply of biomass to replace fossil fuels [41,42]. The substitution factor will largely be related to bioenergy replacing oil or gas, while the ability to create a larger average $C$ stock might be 
smaller $[3,5,43]$. Tree species with a longer rotation cycle, such as late successional spruce, are "slow starters" in early growth in comparison with deciduous species [40]. However, slower growth and longer rotation cycle can be compensated for by a higher average $\mathrm{CO}_{2}$ substitution effect due to a higher share of solid wood products [44] and higher average C stocks at the landscape level $[41,45]$. Therefore, the selection of the best tree species for afforestation in terms of climate benefit should consider all aspects, such as productivity, average $\mathrm{C}$ stock of the cropping system and average substitution factors. So far, there is lack of holistic [3] studies to compare tree species in similar conditions in northern Europe.

Comparison of different tree species' production by combining the studies from the literature will retain a lot of uncertainties that are biased because of the variation of pedoclimatic conditions, latitude, level of tree breeding, measurement years, management practice and land-use history. In order to overcome the uncertainties mentioned, the present study evaluates six different tree species' (silver birch, hybrid aspen, Norway spruce, poplars, larch and willow) climate benefit potential on former agricultural land by using the network of tree species comparison trials in Sweden $[40,46,47]$. The set-up of the experiment is replicated plots in homogenous growth conditions with a similar level of tree breeding, i.e., a tree will have an equal starting point in comparable conditions [46,47]. The early growth data of the trials [40] were used as the basis to model the long-term productivity and calculate the $\mathrm{C}$ pools above- and below-ground for each tree species over several rotation cycles [4].

The present study covers six tree species' (silver birch, willow, larch, Norway spruce, poplar and hybrid aspen) long-term climate benefit after former agricultural land afforestation by combining two aspects: (i) we compare the one-time effect of average $\mathrm{CO}_{2}$ removal from the atmosphere when land-use is changed from agriculture to forestry for all species, and (ii) we estimate the amount of avoided $\mathrm{CO}_{2}$ emissions owing to substitution of fossilbased materials.. The analyses are performed on a hectare scale and according to the scenario of available agricultural land afforestation at the landscape level in northern Europe over a one-hundred-year period.

\section{Materials and Methods}

\subsection{Tree Species}

The input data of different tree species' biomass production estimates are from four experimental sites on former agricultural soils in Sweden, located across the latitudes of $56^{\circ} \mathrm{N}$ (Svalöv), $57^{\circ} \mathrm{N}$ (Länghem), $63^{\circ} \mathrm{N}$ (Bjästa) and $64^{\circ} \mathrm{N}$ (Lövånger) [46,47]. The sites represent typical former arable soil in the given region with a moderate soil fertility [27]. Grain was the main crop of the previous land use, but before afforestation, the sites were fallow or abandoned for up to eight years [40]. A common soil preparation (ploughing and harrowing) and weed control with glyphosate were performed prior to planting [40]. All the sites were surrounded with a fence to avoid game damage [40]. All the sites are non-fertilized [40].

Each experimental site was established in spring 2009 with randomly replicated plots for six different tree species: Norway spruce (Picea abies (L.) Karst), silver birch (Betula pendula Roth), hybrid aspen (Populus tremula L. $\times$ P. tremuloides Michx), poplar (Populus spp., Tacamahaca section), larch (hybrid larch Larix $\times$ eurolepis Henry and Siberian larch L. sukaczewii Dylis) and willow (Salix schwerinii Wolf $\times$ S. viminalis L., 'Tora' and Salix dasyclados Wimm., 'Gudrun'), presented in four blocks $[46,47]$. The selected tree species were considered the most promising for former agricultural land afforestation in the region $[13,18]$. The most advanced genetic material in terms of growth and yield for each region was used and the planting spacing was set to maximize biomass production for each tree species [46,47]. A further description of the origin of the planting material can be found in Rytter and Lutter's work [40].

The spacing of the planted trees was based on self-thinning lines and recommendations for each studied tree species to achieve a maximum biomass production with a certain share of sellable wood assortments $[40,46,47]$. The spacing was 1500 trees per ha for hybrid 
aspen and poplar, 1600 trees per ha for silver birch and larch and 2000 trees per ha for Norway spruce [46]. Willow was planted as cuttings of 14,800 trees per ha [46].

\subsection{Modeling of Site Index Curves, Production and Rotation Cycle}

In order to simplify the production estimates from different latitudes to the regional scale in northern Europe, we pooled (arithmetic mean) the nine-year growth of the four study sites for each tree species in order to model the mean growth rate until the end of the rotation cycle (Supplementary Materials). We assume that this generalization approach of the present study provides a realistic production estimate for the northern Europe region and avoids potential overestimations.

Based on the early growth measurements at the age of nine years in the tree species comparison trials [40], we used the dominant height (thickest 100 trees per ha) to model the site index curves in order to estimate the productivity potential of each tree species (except willow) in comparison with the available curves in Sweden [48]. The site indices $\mathrm{H}_{100}$ and $\mathrm{H}_{50}$ predicted the height of the 100 thickest trees at the age of 100 or 50 years [48]. Site index curves were modeled for each trial location (Supplementary Figure S1). The early growth rate of the first nine years [40] was modeled to describe the stand production in a long-term period according to northern Europe [48-51] for all the studied tree species (Supplementary Tables S1-S9). According to the growth simulations, the rotation cycle for each tree species was taken at the age where the current annual increment (CAI, $\mathrm{m}^{3} \mathrm{ha}^{-1}$ year $^{-1}$ ) drops below the mean annual increment (MAI, $\mathrm{m}^{3} \mathrm{ha}^{-1}$ year ${ }^{-1}$ ) (Supplementary Figure S2). After that, Ozolinš' [52] stem taper curve equations were applied to predict the allocation of wood assortments (sawn logs, pulpwood and energy-wood) for each tree species (Supplementary Figure S3). The production estimates for willow were taken from the empirical measurements from Rytter and Lutter [40] and the detailed description of the growth modeling is presented in the Supplementary Materials.

The share of branches was estimated for each tree species at the end of the first rotation cycle from the literature of biomass studies on former agricultural lands in northern Europe: hybrid aspen and poplar-15\% [23,34], larch - 23\% [39], silver birch - 13\% [30,53] and spruce- $-40 \%$ [37]. There is limited information about the below-ground biomass pools (stable coarse roots) on former agricultural lands after afforestation. We applied an allometric equation $\left(R^{2}=0.78 ; p<0.001\right)$ of mature Populus spp. stands' coarse root biomass for poplar and hybrid aspen [23,54]. The generalized share of $18 \%$ from the above-ground pool was used for birch, larch and spruce $[3,53,55]$. For willow plantations, the estimated share of below-ground biomass coarse roots after coppicing is about $30 \%[3,56]$.

The simulated above-ground volume $\left(\mathrm{m}^{3} \mathrm{ha}^{-1}\right)$ was converted to dry woody biomass $\left(\mathrm{Mg} \mathrm{ha}^{-1}\right)$. We used the basic wood density for each tree species that has been reported in northern Europe on former agricultural lands: hybrid aspen-350 $\mathrm{kg} \mathrm{m}^{-3}$ [23], larch$405 \mathrm{~kg} \mathrm{~m}^{-3}$ [39], poplar-350 $\mathrm{kg} \mathrm{m}^{-3}$ [34], spruce-314 $\mathrm{kg} \mathrm{m}^{-3}$ [37] and silver birch$450 \mathrm{~kg} \mathrm{~m}^{-3}[30,57]$.

The growth data for willow come from the empirical data from the same study sites as willow has past harvest cycles [40]. The length of the rotation cycle for willow was taken as five years, where the first cycle average mean annual increment (MAI) of aboveground biomass (including branches) is $3.6 \mathrm{Mg} \mathrm{ha}^{-1}$ year $^{-1}$ (ranged between 1.9 and $5.0 \mathrm{Mg} \mathrm{ha}^{-1}$ year $^{-1}$ ). It is expected that the production of willow will increase after the first rotation cycle [58]. Based on previous studies in northern Europe [58,59] and the production estimates of the first rotation cycle of the present trials [40], the expected MAI for willow was $6.0 \mathrm{Mg} \mathrm{ha}^{-1}$ year $^{-1}$ for the second rotation. We consider five-year rotation cycles for willow coppicing and 25 years when the clone becomes exhausted and needs replacement. During this 25-year period, the third, fourth and fifth rotation cycle productivity was considered equal to the second harvest cycle. 


\subsection{Carbon Stocks and Substitution}

The standard coefficient of 0.5 was used to convert the dry woody biomass to carbon (C) stock $\left(\mathrm{Mg} \mathrm{C} \mathrm{ha}^{-1}\right)$. The present study focuses on the stable $\mathrm{C}$ stocks of biomass (stems with bark, branches and roots) at the end of the vegetation period modeled at the stand level, and on the climate benefit (substitution) estimation. We define the term "climate benefit" for the next 100 years as the one-time increase in average $C$ stock over a full rotation cycle (stems with bark, branches and roots) plus the accumulated wood substitution effect. The increase in average $C$ stock depends on growth and rotation length and does not change for the subsequent rotation cycles. We assume that the average $C$ stock in crops on the abandoned agricultural land was negligible. Substitution effects are additive over the 100-year period and will depend on assortments harvested and yield. We present the climate benefit $\left(\mathrm{CO}_{2}\right.$ equivalent $\left.\mathrm{Mg} \mathrm{ha}^{-1}\right)$ for each tree species at a hectare scale for the 100-year period and at the landscape scale over the 100-year period according to the assumed afforestation scenario for the region. The effect of different tree species on soil organic $\mathrm{C}$ after former agricultural land afforestation has been recently studied in the early stages of the stand development for some tree species in northern Europe $[23,60,61]$, but the results are scattered and sometimes controversial $[62,63]$. In general, the $C$ accumulation and stabilization depend on many variables (tree species litter quality, previous land-use type, the time period since afforestation, rotation cycle, etc.), which makes the long-term estimations unclear and biased. Based on the arguments mentioned and the scarcity of available data, we did not include the soil $C$ in the present study of climate benefit estimation, assuming no differences between tree species in the development of soil organic $C$ stocks.

Wood products can replace greenhouse gas-intensive materials (concrete, steel) and fossil fuels for energy production, resulting in avoided $\mathrm{CO}_{2}$ emissions [1,2,64]. A substitution factor (or displacement factor) describes how much greenhouse gas emissions would be avoided if a wood-based product is used instead of another product to provide the same function, i.e., how much $C$ emission $(\mathrm{kg} \mathrm{C})$ is avoided per $1 \mathrm{~kg}$ of $\mathrm{C}$ in harvested wood $[1,2,64]$. The displacement factor considers fossil-based emissions from the production chain (e.g., harvesting, transportation, manufacturing, etc.) $[2,65,66]$. The present study assumes intensive forest management practice (e.g., such as for agricultural crops) with $100 \%$ removal of the above-ground tree biomass.

Leskinen et al. [64] recommended an average displacement factor of $1.2 \mathrm{~kg} \mathrm{C} / \mathrm{kg}$ $\mathrm{C}$, which means that each $\mathrm{kg}$ of $\mathrm{C}$ in the wood product resulted in $1.2 \mathrm{~kg}$ of avoided $\mathrm{C}$ emission. Since the different tree species yielded different outcomes of assortments, we have chosen to use different displacement factors for different assortments. Based on the existing literature, we use the mean factor of $0.5 \mathrm{~kg} \mathrm{C} / \mathrm{kg} C$ for energy-wood $[6,64,66]$, $1.5 \mathrm{~kg} \mathrm{C} / \mathrm{kg} \mathrm{C}$ for pulpwood (dissolving pulp and textiles) [64] and $1.3 \mathrm{~kg} \mathrm{C} / \mathrm{kg} \mathrm{C}$ for sawn wood (structural constructions, e.g., buildings, wood frames, beams) [64]. Based on the outcome of wood assortments for each tree species (Supplementary Figure S3), we calculated the total substitution effect for each rotation cycle and the whole study period given the assumptions made. For willow, all the harvested wood is considered as bioenergy. For larch, we calculated only sawn logs and energy-wood substitution as there are no existing methods in the local industry to extract pulp from larch.

\subsection{Afforestation Scenario}

Based on the EU Commission Forest Strategy of 2030 [20] to plant an additional 3 billion trees, we assumed an afforestation scenario for the next 100 years for each tree species. First, we estimate climate benefit over the 100-year period expressed on a hectare scale, then we calculate the total effect on a landscape scale to describe how great the total climate benefit can be by summing up the available area for northern Europe (Estonia, Denmark, Finland, Latvia, Lithuania, Norway and Sweden). The production estimates will be based on the modeling of the early growth of each tree species (Supplementary Materials) in a Swedish experiment [40] and optimizing the rotation cycles based on the 
volume-based maturity age (Supplementary Materials). The focus of the present study is to compare only the differences between tree species $(n=6)$ and not the differences that are attributed to the growth variation from soil and climate conditions in the region [67].

We base the estimate of available area of abandoned agricultural land in northern Europe on Rytter et al.'s work [13]. The distribution between the countries will then be 0.3 million ha in Estonia, 0.3 million ha in Denmark, 0.3 million ha in Finland, 0.3 million ha in Latvia, 0.6 million ha in Lithuania, 0.2 million ha in Norway and 0.3 million ha in Sweden [13]. As afforestation of such a great land area at once might not be realistic, we assumed a scenario where an extensive afforestation campaign of $2 \%(46,000 \mathrm{ha})$ will be realized the first year. Thereafter, afforestation takes place at a steady pace over the next 100 years, that corresponds to $10 \%$ of the first year's efforts, i.e., 4600 ha. This afforestation scenario was simulated for all the studied tree species. In total, the scenario will add 501,400 ha of new forest land after 100 years in the region, corresponding to about $\frac{1}{4}$ of the total available abounded agricultural land area of 2.3 million ha. The chosen scenario is moderate in comparison with the EU Forest Strategy for 2030, where afforestation is expected to cover about 0.2-0.3 million ha per year in Europe [20].

\section{Results}

\subsection{Overview about the Production}

The estimates of growth and yield in the present study are based on modeling of published data by Rytter and Lutter [40]. The modeled site index curves $\left(\mathrm{H}_{100}\right.$ and $\left.\mathrm{H}_{50}\right)$ predict high development and growth potential for all the studied tree species on former agricultural soils (Supplementary Figure S1). At the age of maturity, the MAI of stem wood was highest for larch $\left(18 \mathrm{~m}^{3} \mathrm{ha}^{-1}\right.$ year $\left.^{-1}\right)$, followed by spruce $\left(13 \mathrm{~m}^{3} \mathrm{ha}^{-1}\right.$ year $\left.{ }^{-1}\right)$, poplar and aspen $\left(12 \mathrm{~m}^{3} \mathrm{ha}^{-1}\right.$ year $\left.^{-1}\right)$ and birch $\left(9 \mathrm{~m}^{3} \mathrm{ha}^{-1}\right.$ year $\left.^{-1}\right)$ (Supplementary Figure S2).

\subsection{Sequestration and Substitution in a Hectare Scale}

The one-time climate benefit as a result of increased average $C$ stock (stem wood, branches and roots) was highest for larch ( $386 \mathrm{Mg} \mathrm{CO}_{2}$ eqv. ha $\left.{ }^{-1}\right)$, followed by spruce with a $21 \%$ lower benefit $\left(306 \mathrm{Mg} \mathrm{CO}_{2}\right.$ eqv. ha $\left.{ }^{-1}\right)$. The broadleaved trees afforded similar benefits, but $57-58 \%$ lower than larch (168 $\mathrm{Mg} \mathrm{CO}_{2}$ eqv. ha ${ }^{-1}$ for aspen and poplar, $162 \mathrm{Mg}$ $\mathrm{CO}_{2}$ eqv. ha ${ }^{-1}$ for birch). Willow, with the shortest rotation cycle, afforded the lowest climate benefit related to increased average $\mathrm{C}$ stock $\left(40 \mathrm{Mg} \mathrm{CO}_{2}\right.$ eqv. ha $\left.{ }^{-1}\right)$ (Figure 1).

Additionally, for the climate benefit related to avoided emissions from fossil $\mathrm{C}$ sources and cement, larch showed the highest climate benefit over the analyzed 100-year period (1240 Mg CO 2 eqv. ha ${ }^{-1}$ ) (Figure 2). The broadleaved trees showed similar substitution benefits, ranging from 603 to $619 \mathrm{Mg} \mathrm{CO}_{2}$ eqv. ha ${ }^{-1}$. The climate benefit from avoided emissions by substituting spruce ( $481 \mathrm{Mg} \mathrm{CO}_{2}$ eqv. ha ${ }^{-1}$ ) was $61 \%$ lower than larch and about $20 \%$ lower than for the broadleaves. Willows that were managed with very short rotation cycles and where the substitution effect comes only from the bioenergy afforded a similar climate benefit to spruce related to substitution effects (506 $\mathrm{Mg} \mathrm{CO}_{2}$ eqv. ha ${ }^{-1}$ ) (Figure 2).

Larch produced the highest total climate benefit over the 100-year period $(1626 \mathrm{Mg}$ $\mathrm{CO}_{2}$ eqv. ha $\left.{ }^{-1}\right)$, followed by spruce $\left(788 \mathrm{Mg} \mathrm{CO}_{2}\right.$ eqv. ha $\left.{ }^{-1}\right)$, poplar $\left(779 \mathrm{Mg} \mathrm{CO}_{2}\right.$ eqv. $\left.\mathrm{ha}^{-1}\right)$, birch (782 $\mathrm{Mg} \mathrm{CO}_{2}$ eqv. ha ${ }^{-1}$ ) and hybrid aspen $\left(771 \mathrm{Mg} \mathrm{CO}_{2}\right.$ eqv. ha $\left.{ }^{-1}\right)$. Additionally, for the total climate benefit over the 100-year period, willow performed the worst $\left(546 \mathrm{Mg} \mathrm{CO}_{2}\right.$ eqv. ha ${ }^{-1}$ ), i.e., $66 \%$ less than the respective value for larch. 
a)

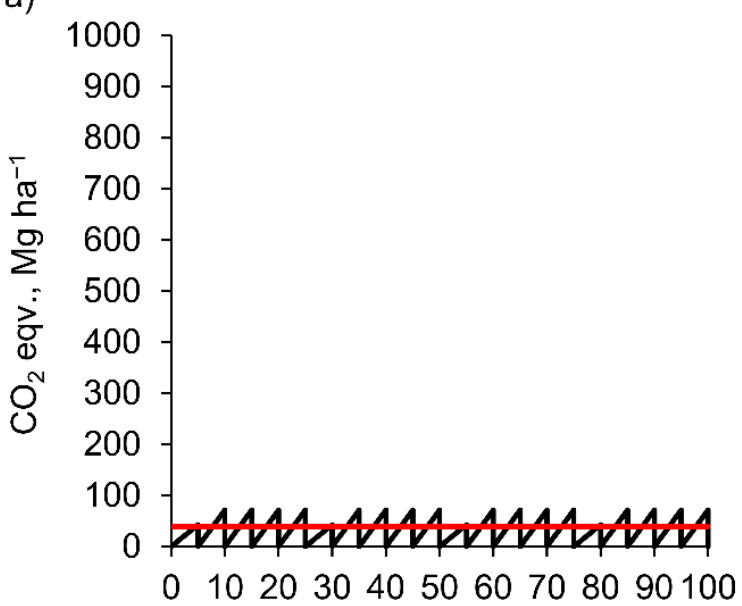

c)

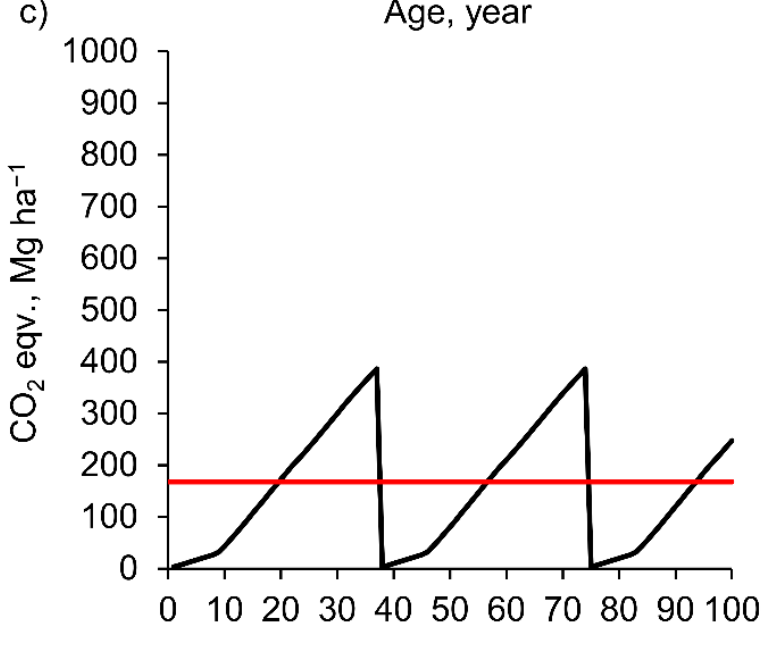

Age, year

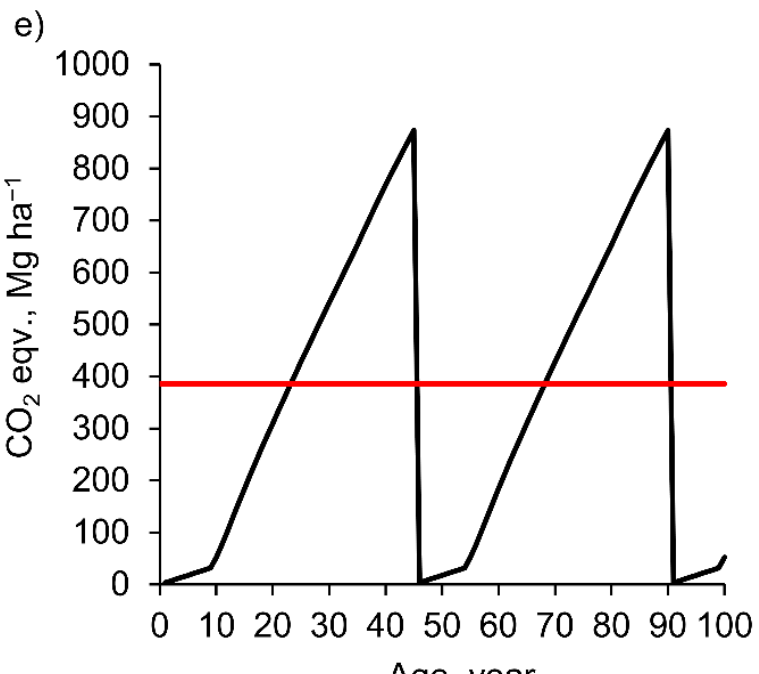

b)

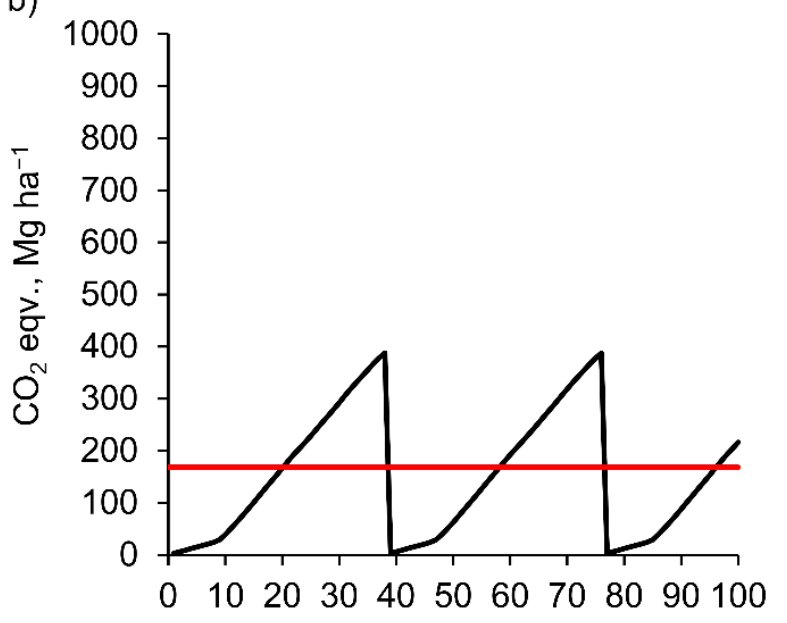

d)

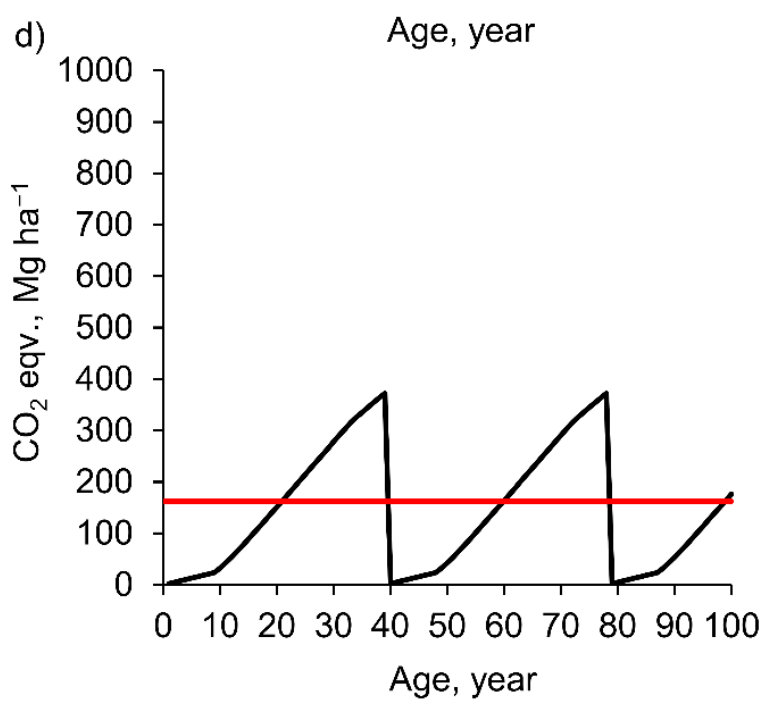

f)

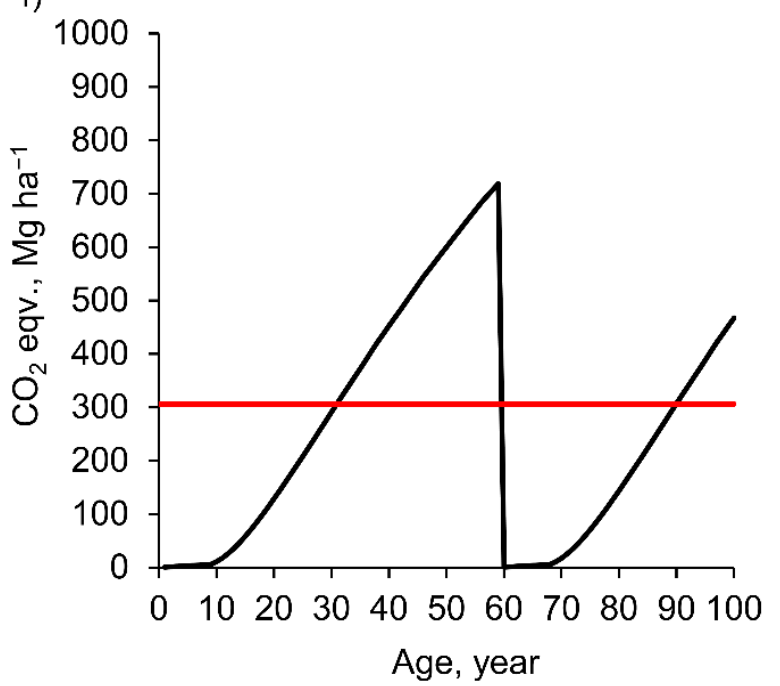

Figure 1. The development of $\mathrm{C}$ stock (expressed as $\mathrm{CO}_{2}$ eqv.) over the rotation cycle and the average $\mathrm{C}$ stock (red line) of a full rotation cycle (stem wood, branches and roots) for willow (a), aspen (b), poplar (c), birch (d), larch (e) and spruce (f). 


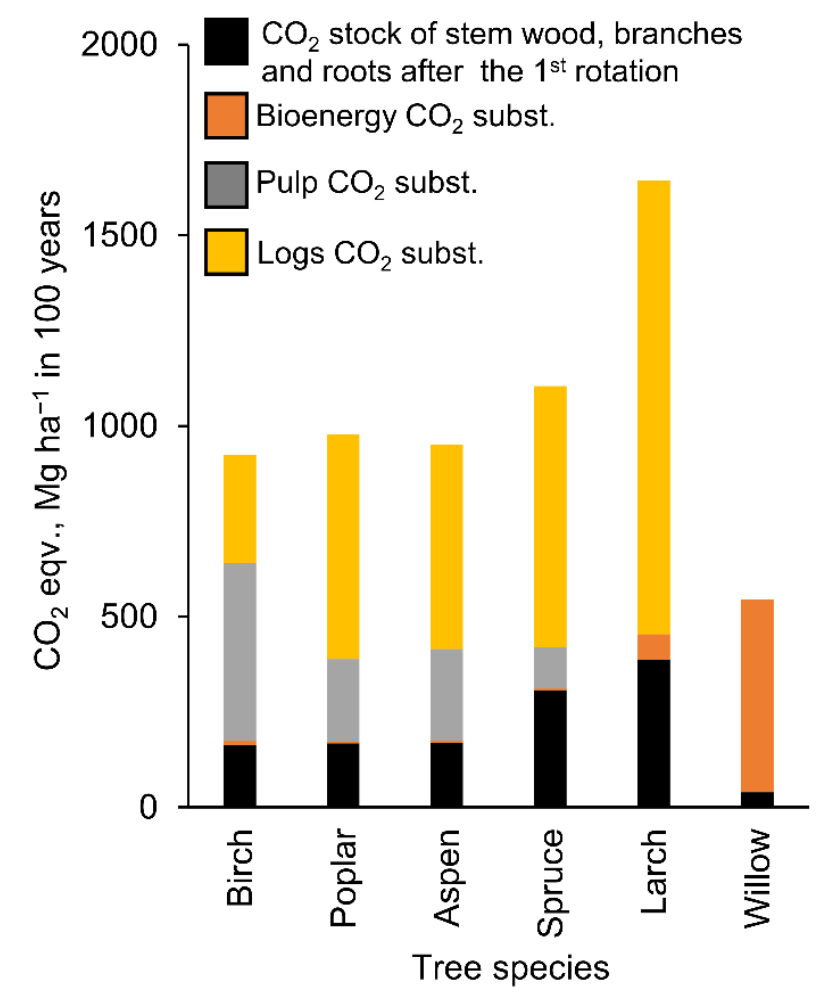

Figure 2. The climate benefit per hectare expressed as the sum of removed $\mathrm{CO}_{2}$ from the atmosphere due to increased carbon stocks and avoided $\mathrm{CO}_{2}$-emissions related to substitution effects over 100 years for the studied tree species.

\subsection{Sequestration and Substitution at the Landscape Scale}

The afforestation scenario for the northern European region with the initial artificial regeneration by planting $2 \%$ of the total available area, corresponding to 46,000 ha and a subsequent afforestation rate of 4600 ha annually during the 100-year period, was modeled for each of the studied tree species (Figure 3). The selected pace of afforestation resulted in a gradual buildup of $C$ stocks at the landscape level. The $C$ stock of willow in the landscape showed a very low but constant increase over the 100-year period (Figure 3). Even though willow can produce the highest total harvest of 264 million $\mathrm{Mg} \mathrm{CO}_{2}$ eqv. (Figure 4), its total $\mathrm{C}$ stock (2.9 million $\mathrm{Mg} \mathrm{CO}_{2}$ eqv.) at the landscape level is smaller than other tree species over the 100-year period (other tree species ranged 63-145 million Mg $\mathrm{CO}_{2}$ eqv.) (Figures 3 and 4). The highest $\mathrm{C}$ stocks at the landscape level were found for the two species with the longest rotation cycles-spruce and larch (Figure 3). Poplar, aspen and birch showed similar $C$ stocks and harvest rates at the landscape level over the 100-year period (Figures 3 and 4 ).

The highest climate benefit at the landscape level, expressed as the sum of the average $\mathrm{C}$ stock increase and accumulated $\mathrm{C}$ substitution effect for the analyzed scenario, was observed for larch (579 million $\mathrm{Mg} \mathrm{CO} 2$ eqv.), followed by spruce (361 million $\mathrm{Mg} \mathrm{CO}_{2}$ eqv.), poplar (309 million $\mathrm{Mg} \mathrm{CO}_{2}$ eqv.), aspen (303 million $\mathrm{Mg} \mathrm{CO}_{2}$ eqv.), birch (296 million $\mathrm{Mg} \mathrm{CO} 2$ eqv.) and willow (161 Million $\mathrm{Mg} \mathrm{CO} 2$ eqv.) (Figure 5). The highest avoided $\mathrm{C}$ emissions were from larch stands when the wood goes to sawn logs (232 million $\mathrm{MgCO}_{2}$ eqv.) (Figure 5). The total climate benefit of larch was about 1.6-3.6 times higher than for the other tree species (Figure 5). 




Figure 3. The development of the climate benefit at the landscape level according to the analyzed scenario expressed as the sum of removed $\mathrm{CO}_{2}$ from the atmosphere due to increased carbon stocks and avoided $\mathrm{CO}_{2}$-emissions related to substitution effects over 100 years for the studied tree species.

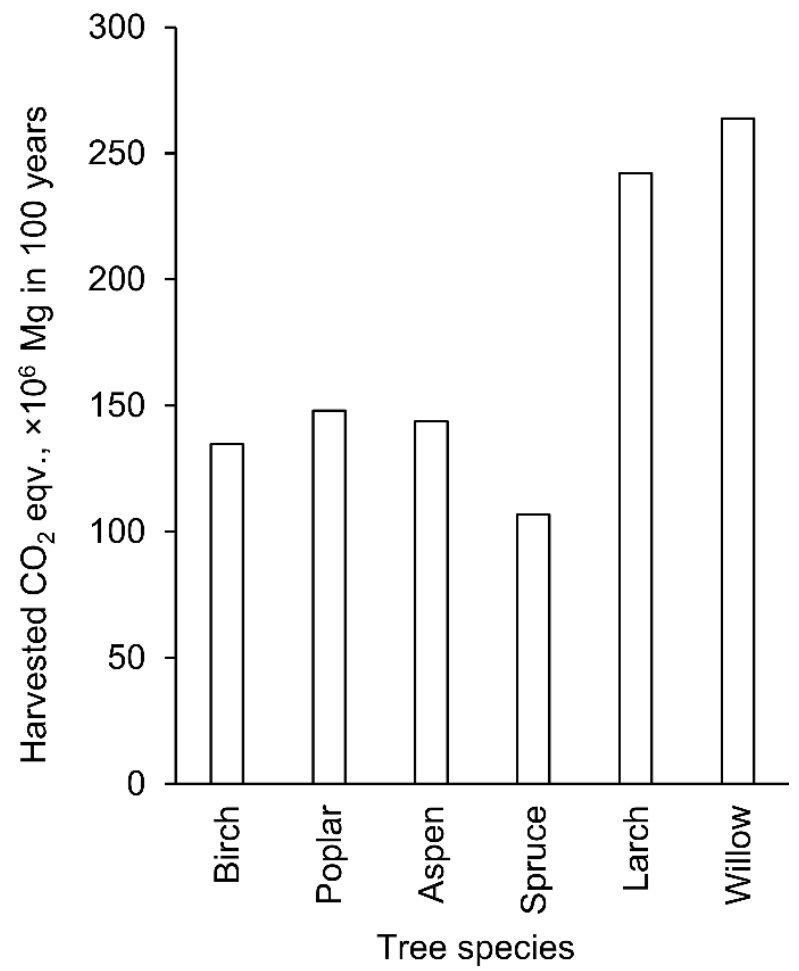

Figure 4. The sum of harvested wood expressed as $\mathrm{CO}_{2}$ eqv during the 100-year period for different tree species at the landscape level. 


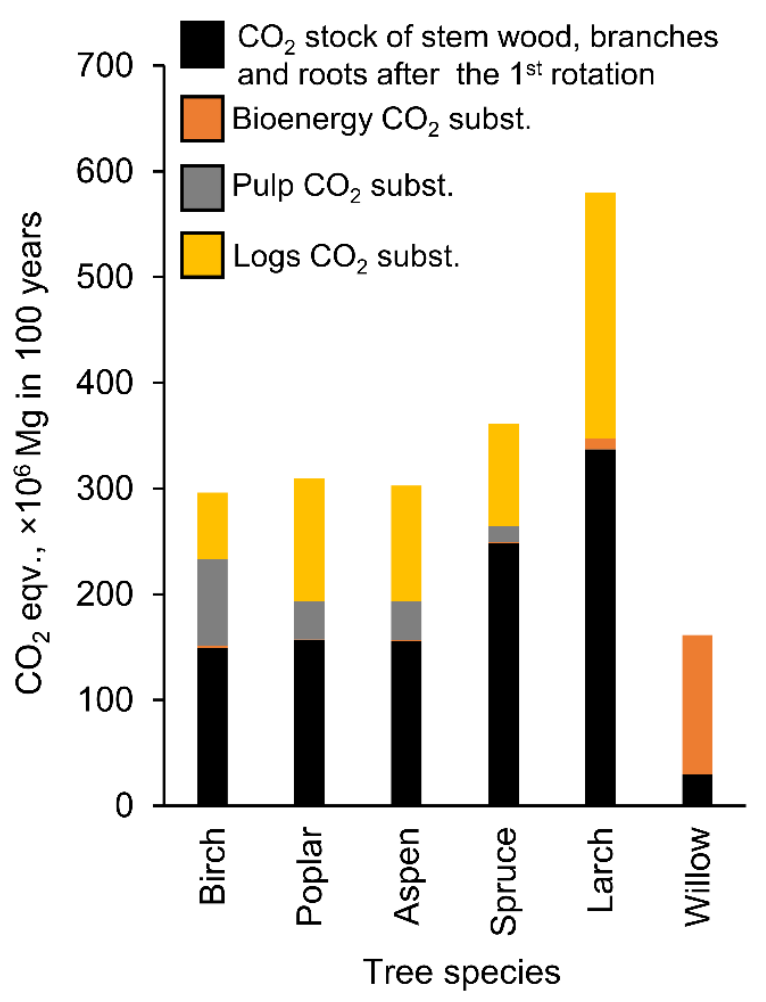

Figure 5. The total climate benefit at the landscape level according to the analyzed scenario expressed as the sum of removed $\mathrm{CO}_{2}$ from the atmosphere due to increased carbon stocks and avoided $\mathrm{CO}_{2}$-emissions related to substitution effects over 100 years for the studied tree species.

\section{Discussion}

The results of this study show that factors such as the annual average growth, the length of the rotation cycle and the outcome of assortments from harvested wood are all of great importance for the total climate benefit that arises from afforestation. Forest growth and the outcome of assortments governs how great the total climate benefit can be, while the length of the rotation cycle determines at what time it arises [68].

The significance of the outcome of the assortments was particularly clear for willow, where high growth and the highest harvest with short rotation cycles still afforded the lowest climate benefit for the analyzed landscape scenario, as the only assortment was biofuel with a relatively low substitution factor and the buildup of average carbon stock during a rotation cycle was small. The highest climate benefit was provided by larch, which had high growth, yielded a large proportion of raw material with a high substitution factor and had the largest buildup of average carbon stock during a rotation cycle that also allowed two harvests during the analysis period. Spruce, birch, aspen and poplar all showed approximately the same total climate benefit, but the spruce's longer rotation cycle resulted in only one harvest being carried out within the analyzed period. We chose the period as 100 years, but had the analysis period been longer so that the spruce could also be harvested twice, the difference between larch and spruce would have decreased.

In the case of land-use change to forest, a gradually increasing climate benefit arises as a result of $\mathrm{CO}_{2}$ being absorbed and stored in living biomass (mainly in stems) as the trees grow, and by that, $\mathrm{CO}_{2}$ is removed from the atmosphere. When the trees have grown fully and are harvested, another type of climate benefit arises linked to the fact that fossil products and cement can be replaced by the use of forest-based products [1-3]. At the same time as the trees are harvested, a large part of the carbon stock that has built up in living biomass is lost. Some of the carbon in the harvested trees is returned directly to the atmosphere, but a proportion can be temporarily stored in different types of forest products, therefore having a longer residence time before returning as $\mathrm{CO}_{2}$ to the atmosphere [64]. 
At the property level, it is therefore the average carbon stock during the first rotation cycle that determines how much $\mathrm{CO}_{2}$ is removed from the atmosphere. It then also becomes a measure of how much $\mathrm{CO}_{2}$, on average, and thus potentially permanently, is removed from the atmosphere, and that can be linked to a specific property. We believe that this is an accurate way to calculate climate benefit related to $C$ stock changes because it then lasts as long as the land continues to be managed with the same tree species as a crop. This way of calculating could be the basis for pricing the $C$ sink in a voluntary market for trading in C credits.

The second type of climate benefit, related to avoided emissions through substitution of fossil-based resources, is not straightforward and sometimes difficult to quantify, and thus involves many uncertainties. This climate benefit arises outside the property boundary and is linked to different products, and its value is indirectly reflected in the price volatility of the raw material (e.g., pulpwood price is low and then it goes to energy-wood, which lowers the climate benefit of birch, aspen and poplar) [69]. We have chosen to base substitution factors on data from the literature [64] and assessed them as reasonable, but we also acknowledge that the uncertainty increases over time in the scenario analysis that has been performed. If we had chosen other substitution factors, the ranking between tree species would not change unless bioenergy was considered to have a significantly higher substitution factor in the future. An increased substitution factor for bioenergy would primarily increase the overall climate benefit of willow.

Trees on average contain much more $C$ during the rotation period than the crops normally growing on abandoned arable land. We have assumed that the arable crop's C stock is negligible, which means that we to some extent overestimate the benefit of increasing the carbon stock in the living biomass of trees. On the other hand, we have not included the build-up of $C$ stock that occurs in forest products when wood raw material is harvested.

This study illustrated the dual climate benefit of the forest, but it also showed that the total climate benefit varies when reforesting abandoned agricultural land depending on which tree species is chosen. The greatest climate benefit resulted from afforestation using larch, both at the stand level and the landscape level in the analyzed scenario. The advantages of larch can be explained by two factors. Firstly, high growth, together with a rather long rotation cycle, resulted in a high average $C$ stock and room for a large harvest of raw material. The high growth for larch on abandoned agricultural land in our model $\left(18 \mathrm{~m}^{3} \mathrm{ha}^{-1}\right.$ year $\left.^{-1}\right)$ has also been reported in other case studies in northern Europe [39]. Secondly, the high climate benefit from larch comes from the high substitution effect and large quantities of harvested wood. Afforestation with larch forests in the region is so far not common, for example comprising only $0.1 \%$ of all tree species (growing stock) in Sweden [39]. Spruce was the second-best choice. A disadvantage with spruce on agricultural land is the vulnerability to climate change consequences, where spruce stands might be damaged by root diseases, storms and bark beetle attacks [70,71]. One thing we have not analyzed in this study is the possibility of growing mixed forest, where spruce is included as a tree species. An opportunity to reduce the risk of forest damage could thus be to grow spruce in mixed forests together with deciduous tree species such as aspen, poplar or birch [72].

Although the analyzed landscape scenario only corresponds to about $\frac{1}{4}$ of the proposed target in the EU and the implementation time is assumed to be significantly longer, the results, which amount to between 161 and 579 million $\mathrm{Mg} \mathrm{CO}_{2}$ eqv., show that a significant total climate benefit can be obtained if all available land were to be afforested.

The long-term modeling of our study did not consider the responses of tree species' performance related to climate change consequences. The predictions of climate change consequences may indicate shifts in tree species' distribution and selection in Europe, where drought tolerance could be a critical characteristic [73,74]. In general, the northern European region is predicted to have increased precipitation and a longer growing season, i.e., increased production and a potential to grow a wider choice of tree species (e.g., 
deciduous species) at higher latitudes [75]. The improved production of deciduous species has already been shown for the present experiment, with a relatively high production at the two most northerly sites (over $60^{\circ} \mathrm{N}$ ) [40]. The concept of forest plantations in our study allows the replacement of endangered tree species for resistant ones if an unexpected dieback occurs as a result of climate change.

In summary, we conclude that afforestation of abandoned agricultural land is an effective measure to mitigate climate change. The choice of tree species is important for the total climate benefit that can be achieved, and forest management should be adapted to local conditions to maximize tree growth. At the property level, the climate benefit can be quantified as the increased $C$ stock in the living tree biomass, expressed as an average over the first rotation cycle. Birch, aspen and poplar, and especially spruce and larch, are all good candidates for contributing to significant climate benefits in northern Europe.

Supplementary Materials: The following are available online at https:/ / www.mdpi.com/article/10 $.3390 /$ f12121810/s1, Figure S1: Site index curves, Figure S2: Predicted production, Figure S3: fraction of wood assortments, Tables S1-S9. References [76,77] are cited in the supplementary materials.

Author Contributions: Conceptualization, T.L. and R.L.; methodology, R.L. and T.L.; formal analysis, R.L.; writing—review and editing, all authors; visualization, R.L.; funding acquisition, T.L. All authors have read and agreed to the published version of the manuscript.

Funding: The study was funded by Knut and Alice Wallenberg foundation (research program Future Silviculture), by the Estonian Research Council, grant numbers PRG1007, PSG600, PSG730 and MOBTP168, and by the European Commission's Horizon 2020 program under grant agreement number 101000406 (project ONEforest).

Data Availability Statement: Data are available upon request from the corresponding author.

Acknowledgments: Authors are thankful to Lars Rytter for the initial input data from Rytter and Lutter (2020) [40].

Conflicts of Interest: The authors declare no conflict of interest.

\section{References}

1. Eriksson, E.; Gillespie, A.; Gustavsson, L.; Langvall, O.; Olsson, M.; Sathre, R.; Stendahl, J. Integrated carbon analysis of forest management practices and wood substitution. Can. J. For. Res. 2007, 37, 671-681. [CrossRef]

2. Sathre, R.; O'Connor, J. Meta-analysis of greenhouse gas displacement factors of wood product substitution. Environ. Sci. Policy 2010, 13, 104-114. [CrossRef]

3. Sántha, E.; Bentsen, N.S. Ecosystem Service Benefits and Trade-Offs-Selecting Tree Species in Denmark for Bioenergy Production. Forests 2020, 11, 277. [CrossRef]

4. Lundmark, T.; Bergh, J.; Hofer, P.; Lundström, A.; Nordin, A.; Poudel, B.C.; Sathre, R.; Taverna, R.; Werner, F. Potential Roles of Swedish Forestry in the Context of Climate Change Mitigation. Forests 2014, 5, 557-558. [CrossRef]

5. Lundmark, T.; Bergh, J.; Nordin, A.; Fahlvik, N.; Poudel, B.C. Comparison of carbon balances between continuous-cover and clear-cut forestry in Sweden. Ambio 2016, 45, 203-213. [CrossRef]

6. Petersson, H.; Ellison, D.; Appiah Mensah, A.; Berndes, G.; Egnell, G.; Lundblad, M.; Lundmark, T.; Lundström, A.; Stendahl, J.; Wikberg, P.E. On the role of forests and the forest sector for climate change mitigation in Sweden. Zenodo 2021. [CrossRef]

7. McCormick, K.; Kautto, N. The Bioeconomy in Europe: An Overview. Sustainability 2013, 5, 2589-2608. [CrossRef]

8. Haapala, A.; Härkönen, J.; Leviäkangas, P.; Kess, P.; Häggman, H.; Arvola, J.; Stoor, T.; Ämmäla, A.; Karppinen, K.; Leppilampi, M.; et al. Bioeconomy potential-Focus on Northern Finland. Int. J. Sustain. Econ. 2014, 7, 66-90. [CrossRef]

9. Berndes, G.; Abt, B.; Asikainen, A.; Cowie, A.; Dale, V.; Egnell, G.; Lindner, M.; Paré, D.; Pingoud, K.; Yeh, S. Forest biomass, carbon neutrality and climate change mitigation. Sci. Policy Eur. For. Inst. 2016, 3, 3-27. [CrossRef]

10. European Commission. Innovating for Sustainable Growth. A Bioeconomy for Europe; European Commission: Luxembourg, 2012; 59p, Available online: https:/ / publications.europa.eu/en/publication-detail/-/publication/1f0d8515-8dc0-4435-ba53-9570e47dbd51 (accessed on 16 November 2021).

11. The European Green Deal. Communication from the Commission, Brussels 2019. Available online: https://ec.europa.eu/info/ sites/info/files/european-green-deal-communication_en.pdf (accessed on 16 December 2021).

12. Proskurina, S.; Sikkema, R.; Heinimö, J.; Vakkilainen, E. Five years left-How are the EU member states contributing to the 20\% target for EU's renewable energy consumption; the role of woody biomass. Biomass Bioenergy 2016, 95, 64-77. [CrossRef] 
13. Rytter, L.; Ingerslev, M.; Kilpeläinen, A.; Torssonen, P.; Lazdina, D.; Löf, M.; Madsen, P.; Muiste, P.; Stener, L.-G. Increased forest biomass production in the Nordic and Baltic countries-A review on current and future opportunities. Silva Fenn. 2016, 50, id1660. [CrossRef]

14. Ollikainen, M. Forestry in bioeconomy-Smart green growth for the humankind. Scand. J. For. Res. 2014, 29, 360-366. [CrossRef]

15. Angelstam, P.; Naumov, V.; Elbakidze, M.; Manton, M.; Priednieks, J.; Rendenieks, Z. Wood production and biodiversity conservation are rival forestry objectives in Europe's Baltic Sea Region. Ecosphere 2018, 9, e02119. [CrossRef]

16. Eyvindson, K.; Repo, A.; Monkkonen, M. Mitigating forest biodiversity and ecosystem service losses in the era of bio- based economy. For. Policy Econ. 2018, 92, 119-127. [CrossRef]

17. Paris Agreement. 2015. 25p. Available online: https://unfccc.int/sites/default/files/english_paris_agreement.pdf (accessed on 16 December 2021).

18. Tullus, H.; Tullus, A.; Rytter, L. Short-rotation forestry for supplying biomass for energy production. In Forest BioEnergy Production: Management, Carbon Sequestration and Adaptation; Kellomäki, S., Kilpeläinen, A., Ashraful, A., Eds.; Springer: New York, NY, USA; Heidelberg, Germany; Dordercht, The Netherlands, 2013; pp. 39-56.

19. Bastin, J.-F.; Finegold, Y.; Garcia, C.; Mollicone, D.; Rezende, M.; Routh, D.; Zohner, C.M.; Crowther, T.W. The global tree restoration potential. Science 2019, 365, 76-79. [CrossRef]

20. European Commission. The 3 Billion Tree Planting Pledge for 2030. 2021. 53p. Available online: https://ec.europa.eu/ environment/pdf/forests/swd_3bn_trees.pdf (accessed on 16 December 2021).

21. Weih, M. Intensive short rotation forestry in boreal climates: Present and future perspectives. Can. J. For. Res. 2004, 34, 369-1378. [CrossRef]

22. Lankoski, J.; Ollikainen, M. Biofuel policies and the environment: Do climate benefits warrant increased production from biofuel feedstocks? Ecol. Econ. 2011, 70, 676-687. [CrossRef]

23. Lutter, R.; Tullus, A.; Kanal, A.; Tullus, T.; Tullus, H. The impact of former land-use type to above- and below-ground C and N pools in short-rotation hybrid aspen (Populus tremula L. $\times$ P. tremuloides Michx.) plantations in hemiboreal conditions. For. Ecol. Manag. 2016, 378, 79-90. [CrossRef]

24. Randlane, T.; Tullus, T.; Saag, A.; Lutter, R.; Tullus, A.; Helm, A.; Tullus, H.; Pärtel, M. Diversity of lichens and bryophytes in hybrid aspen plantations in Estonia depends on landscape structure. Can. J. For. Res. 2017, 47, 1202-1214. [CrossRef]

25. Englund, O.; Börjesson, P.; Berndes, G.; Scarlat, N.; Dallemand, J.F.; Grizzetti, B.; Dimitriou, I.; Mola-Yudego, B.; Fahl, F. Beneficial land use change: Strategic expansion of new biomass plantations can reduce environmental impacts from EU agriculture. Glob. Environ. Chang. 2020, 60, 101990. [CrossRef]

26. Nord-Larsen, T.; Sevel, L.; Raulund-Rasmussen, K. Commercially Grown Short Rotation Coppice Willow in Denmark: Biomass Production and Factors Affecting Production. BioEnergy Res. 2015, 8, 325-339. [CrossRef]

27. Rytter, R.M.; Rytter, L.; Högbom, L. Carbon sequestration in Willow (Salix spp.) plantations on former areable land estimated by repeated field sampling and C budget calculations. Biomass Bioenergy 2015, 83, 483-492. [CrossRef]

28. Rytter, L.; Rytter, R.M. Growth and carbon capture of grey alder (Alnus incana (L.) Moench.) under north European conditionsEstimates based on reported research. For. Ecol. Manag. 2016, 373, 56-65. [CrossRef]

29. Uri, V.; Kukumägi, M.; Aosaar, J.; Varik, M.; Becker, H.; Soosaar, K.; Morozov, G.; Ligi, K.; Padari, A.; Ostonen, I.; et al. Carbon budgets in fertile grey alder (Alnus incana (L.) Moench.) stands of different ages. For. Ecol. Manag. 2017, 396, 55-67. [CrossRef]

30. Johansson, T. Biomass production and allometric above- and below-ground relations for young birch stands planted at four spacings on abandoned farmland. Forestry 2006, 80, 41-52. [CrossRef]

31. Lutter, R.; Tullus, A.; Kanal, A.; Tullus, T.; Vares, A.; Tullus, H. Growth development and plant-soil relations in mid-term silver birch (Betula pendula Roth) plantations on previous agricultural lands in hemiboreal Estonia. Eur. J. For. Res. 2015, $134,653-667$. [CrossRef]

32. Rytter, L.; Stener, L.G. Growth and thinning effects during a rotation period of hybrid aspen in southern Sweden. Scand. J. For. Res. 2014, 29, 747-756. [CrossRef]

33. Lutter, R.; Tullus, A.; Kanal, A.; Tullus, T.; Tullus, H. Above-ground growth and temporal plant-soil relations in midterm hybrid aspen (Populus tremula L. $\times$ P. tremuloides Michx.) plantations on former arable lands in hemiboreal Estonia. Scand. J. Forest Res. 2017, 8, 688-699. [CrossRef]

34. Johansson, T.; Karacic, A. Increment and biomass in hybrid poplar and some practical implications. Biomass Bioenergy 2011, 35, 1925-1934. [CrossRef]

35. Nielsen, U.B.; Madsen, P.; Hansen, J.K.; Nord-Larsen, T.; Nielsen, A.Y. Production potential of 36 poplar clones grown at medium length rotation in Denmark. Biomass Bioenergy 2014, 64, 99-109. [CrossRef]

36. Georgiadis, P.; Vesterdal, L.; Stupak, I.; Raulund-Rasmussen, K. Accumulation of soil organic carbon after cropland conversion to short-rotation willow and poplar. GCB Bioenergy 2017, 9, 1390-1401. [CrossRef]

37. Johansson, T. Biomass Production of Norway Spruce (Picea abies (L.) Karst.) Growing on Abandoned Farmland. Silva Fenn. 1999, 33, 261-280. [CrossRef]

38. Johansson, T. Total Stem and Merchantable Volume Equations of Norway Spruce (Picea abies (L.) Karst.) Growing on Former Farmland in Sweden. Forests 2014, 5, 2037-2049. [CrossRef]

39. Johansson, T. Biomass equations for hybrid larch growing on farmland. Biomass Bioenergy 2013, 49, 152-159. [CrossRef] 
40. Rytter, L.; Lutter, R. Early growth of different tree species on agricultural land along a latitudinal transect in Sweden. Forestry 2020, 93, 376-388. [CrossRef]

41. Favero, A.; Mendelsohn, R.; Sohngen, B. Using forests for climate mitigation: Sequester carbon or produce woody biomass? Clim. Chang. 2017, 144, 195-206. [CrossRef]

42. Staples, M.D.; Malina, R.; Suresh, P.; Hileman, J.I.; Barrett, S.R.H. Aviation $\mathrm{CO}_{2}$ emissions reductions from the use of alternative jet fuels. Energy Policy 2017, 114, 342-354. [CrossRef]

43. Kalt, G.; Mayer, A.; Theurl, M.C.; Lauk, C.; Erb, K.H.; Haberl, H. Natural climate solutions versus bioenergy: Can carbon benefits of natural succession compete with bioenergy from short rotation coppice? GCB Bioenergy 2019, 11, 1283-1297. [CrossRef] [PubMed]

44. Gustavsson, I.; Pingoud, K.; Sathre, R. Carbon dioxide balance of wood substitution: Comparing concrete- and wood-framed buildings. Mitig. Adapt. Strateg. Glob. Chang. 2006, 11, 667-691. [CrossRef]

45. Taeroe, A.; Mustapha, W.F.; Stupak, I.; Raulund-Rasmussen, K. Do forests best mitigate $\mathrm{CO}_{2}$ emissions to the atmosphere by setting them aside for maximization of carbon storage or by management for fossil fuel substitution? J. Environ. Manag. 2017, 197, 117-129. [CrossRef]

46. Rytter, L.; Lundmark, T. Trädslagsförsök Med Inriktning på Biomassaproduktion [Tree Species Trial with Emphasis on Biomass ProductionStage 2]; Arbetsrapport no. 837; Skogforsk: Uppsala, Sweden, 2014; 24p.

47. Rytter, L.; Lundmark, T. Trädslagsförsök Med Inriktning på Biomassaproduktion-Etapp 2 [Tree Species Trial with Emphasis on Biomass Production]; Arbetsrapport no. 724; Skogforsk: Uppsala, Sweden, 2010; 20p.

48. Johansson, U.; Ekö, P.M.; Elfving, B.; Johansson, T.; Nilsson, U. Nya höjdutvecklingskurvor för bonitering. Fakta Skog 2013, 14, 6.

49. Elfving, B.; Kiviste, A. Construction of site index equations for Pinus sylvestris L. using permanent plot data in Sweden. For. Ecol. Manag. 1997, 98, 125-134. [CrossRef]

50. Kiviste, A. An algebraic difference model for the forest growth simulation in Estonia. Trans. Est. Agric. Univ. 1997, 189, 63-75.

51. Kiviste, A.; Kiviste, K. Algebraic difference equations for stand height, diameter, and volume depending on stand age and site factors for Estonian state forests. Math. Comput. For. Nat.-Resour. Sci. 2009, 1, 67-77.

52. Ozolinš, R. Forest stand assortment structure analysis using mathematical modelling. For. Stud. 2002, $37,33-42$.

53. Uri, V.; Varik, M.; Aosaar, J.; Kanal, A.; Kukumägi, M.; Lõhmus, K. Biomass production and carbon sequestration in a fertile silver birch (Betula pendula Roth) forest chronosequence. For. Ecol. Manag. 2012, 267, 117-126. [CrossRef]

54. Fortier, J.; Truax, B.; Gagnon, D.; Lambert, F. Plastic Allometry in Coarse Root Biomass of Mature Hybrid Poplar Plantations. Bioenergy Res. 2015, 8, 1691-1704. [CrossRef]

55. Addo-Danso, S.; Prescott, C.E.; Smith, A.R. Methods for estimating root biomass and production in forest and woodland ecosystem carbon studies: A review. For. Ecol. Manag. 2016, 359, 332-351. [CrossRef]

56. Pacaldo, R.S.; Volk, T.A.; Briggs, R.D. Greenhouse Gas Potentials of Shrub Willow Biomass Crops Based on Below- and Aboveground Biomass Inventory Along a 19-Year Chronosequence. Bioenergy Res. 2013, 6, 252-262. [CrossRef]

57. Repola, J. Models for vertical wood density of Scots pine, Norway spruce and birch stems, and their application to determine average wood density. Silva Fenn. 2006, 40, 322. [CrossRef]

58. Dimitriou, I.; Rosenqvist, H.; Berndes, G. Slow expansion and low yields of willow short rotation coppice in Sweden; implications for future strategies. Biomass Bioenergy 2011, 35, 4613-4618. [CrossRef]

59. Nordborg, M.; Berndesm, G.; Dimitriou, I.; Henriksson, A.; Mola-Yudego, B.; Rosenqvist, H. Energy analysis of willow production for bioenergy in Sweden. Renew. Sustain. Energy Rev. 2018, 93, 473-482. [CrossRef]

60. Rahman, M.M.; Bárcena, T.G.; Vesterdal, L. Tree species and time since afforestation drive soil C and N mineralization on former cropland. Geoderma 2017, 305, 153-161. [CrossRef]

61. Rytter, R.M.; Rytter, L. Carbon sequestration at land use conversion-Early changes in total carbon stocks for six tree species grown on former agricultural land. For. Ecol. Manag. 2020, 466, 118129. [CrossRef]

62. Vesterdal, L.; Clarke, N.; Sigurdsson, B.; Gundersen, P. Do tree species influence soil carbon stocks in temperate and boreal forests? For. Ecol. Manag. 2013, 309, 4-18. [CrossRef]

63. Bárcena, T.G.; Kiær, L.P.; Vesterdal, L.; Stefánsdóttir, H.M.; Gundersen, P.; Sigurdsson, B.D. Soil carbon stock change following afforestation in Northern Europe: A meta-analysis. Glob. Chang. Biol. 2014, 20, 2393-2405. [CrossRef]

64. Leskinen, P.; Cardellini, G.; González-García, S.; Hurmekoski, E.; Sathre, R.; Seppälä, J.; Smyth, C.; Stern, T.; Verkerk, P.J. Substitution effects of wood-based products in climate change mitigation. In Science to Policy 7; European Forest Institute: Joensuu, Finland, 2018; Volume 7, 27p. [CrossRef]

65. Wihersaari, M. Greenhouse gas emissions from final harvest fuel chip production in Finland. Biomass Bioenergy 2005, 28, 435-443. [CrossRef]

66. Smyth, C.; Rampley, G.; Lemprière, T.C.; Schwab, O.; Kruz, W.A. Estimating product and energy substitution benefits in national-scale mitigation analyses for Canada. GCB Bioenergy 2017, 9, 1071-1084. [CrossRef]

67. Mola-Yudego, B.; Arevalo, J.; Díaz-Yáñez, O.; Dimitriou, I.; Haapala, A.; Carlos Ferraz Filho, A.; Selkimäki, M.; Valbuena, R. Wood biomass potentials for energy in northern Europe: Forest or plantations? Biomass Bioenergy 2017, 106, 95-103. [CrossRef]

68. Lundmark, T.; Poudel, B.C.; Stål, G.; Nordin, A.; Sonesson, J. Carbon balance in production forestry in relation to rotation length. Can. J. For. Res. 2018, 48, 672-678. [CrossRef] 
69. Hepner, H.; Lukason, O.; Lutter, R.; Padari, A.; Tullus, A.; Tullus, H. The Value of Hybrid Aspen Coppice Investment under Different Discount Rate, Price and Management Scenarios: A Case Study of Estonia. Forests 2021, 12, 1332. [CrossRef]

70. Seidl, R.; Vigl, F.; Rössler, G.; Neumann, M.; Rammer, W. Assessing the resilience of Norway spruce forests through a model-based reanalysis of thinning trials. For. Ecol. Manag. 2017, 388, 3-12. [CrossRef] [PubMed]

71. Jakoby, O.; Lischke, H.; Wermelinger, B. Climate change alters elevational phenology patterns of the European spruce bark beetle (Ips typographus). Glob. Chang. Biol. 2019, 25, 4048-4063. [CrossRef]

72. Felton, A.; Nilsson, U.; Sonesson, J.; Felton, A.M.; Roberge, J.M.; Ranius, T.; Ahlström, M.; Bergh, J.; Björkman, C.; Boberg, J.; et al. Replacing monocultures with mixed-species stands: Ecosystem service implications of two production forest alternatives in Sweden. Ambio 2016, 45, 124-139. [CrossRef] [PubMed]

73. Dyderski, M.K.; Paz, S.; Frelich, L.E.; Jagodzinski, A.M. How much does climate change threaten European forest tree species distributions? Glob. Chang. Biol. 2017, 24, 1150-1163. [CrossRef]

74. Puchalka, R.; Dyderski, M.K.; Vítková, M.; Sádlo, J.; Klisz, M.; Netsvetov, M.; Prokopuk, Y.; Matisons, R.; Mionskowski, M.; Wojda, T.; et al. Black locust (Robinia pseudoacacia L.) range contraction and expansion in Europe under changing climate. Glob. Chang. Biol. 2020, 27, 1587-1600. [CrossRef] [PubMed]

75. Lindner, M.; Fitzgerald, J.B.; Zimmermann, N.E.; Reyer, C.; Delzon, S.; van der Maaten, E.; Schelhaas, M.J.; Lasch, P.; Eggers, J.; van der Maaten-Theunissen, M.; et al. Climate change and European forests: What do we know, what are the uncertainties, and what are the implications for forest management? J. Environ. Manag. 2014, 146, 69-83. [CrossRef]

76. Forest Planning Guidance. 2009. Accepted on 16 January 2009. RTL 2009, 9, 104. Available online: https:/ /www.riigiteataja.ee/ akt/131082018008?leiaKehtiv (accessed on 16 December 2021). (In Estonian).

77. Padari, A. Mathematical analysis and modification possibilities of Ozolinš taper curve on the example of Hiiumaa pines. For. Stud. 2020, 72, 34-53. 